University of Nebraska - Lincoln

DigitalCommons@University of Nebraska - Lincoln

\title{
Subspecies Status and Population Genetic Structure in Piping Plover (Charadrius melodus)
}

Mark P. Miller

U.S. Geological Survey, mpmiller@usgs.gov

Susan M. Haig

U.S. Geological Survey, Susan_Haig@usgs.gov

Cheri L. Gratto-Trevor

Prairie and Northern Wildlife Research Centre

Thomas D. Mullins

U.S. Geological Survey, tom_mullins@usgs.gov

Follow this and additional works at: https://digitalcommons.unl.edu/usgsstaffpub

Part of the Geology Commons, Oceanography and Atmospheric Sciences and Meteorology Commons, Other Earth Sciences Commons, and the Other Environmental Sciences Commons

Miller, Mark P.; Haig, Susan M.; Gratto-Trevor, Cheri L.; and Mullins, Thomas D., "Subspecies Status and Population Genetic Structure in Piping Plover (Charadrius melodus)" (2010). USGS Staff -- Published Research. 666.

https://digitalcommons.unl.edu/usgsstaffpub/666

This Article is brought to you for free and open access by the US Geological Survey at DigitalCommons@University of Nebraska - Lincoln. It has been accepted for inclusion in USGS Staff -- Published Research by an authorized administrator of DigitalCommons@University of Nebraska - Lincoln. 


\title{
SUBSPECIES STATUS AND POPULATION GENETIC STRUCTURE IN PIPING PLOVER (CHARADRIUS MELODUS)
}

\author{
Mark P. Miller, ${ }^{1,3}$ Susan M. Haig, ${ }^{1}$ Cheri L. Gratto-Trevor, ${ }^{2}$ \\ AND ThOMAS D. MULLINS ${ }^{1}$
}

${ }^{1}$ U.S. Geological Survey Forest and Rangeland Ecosystem Science Center, 3200 SW Jefferson Way, Corvallis, Oregon 97331, USA; and

${ }^{2}$ Prairie and Northern Wildlife Research Centre, Environment Canada, 115 Perimeter Road, Saskatoon, Saskatchewan S7N 0X4, Canada

\begin{abstract}
Piping Plover (Charadrius melodus) is a migratory shorebird that is listed as endangered in Canada and the U.S. Great Lakes and as threatened throughout the rest of its breeding and winter range. We undertook a comprehensive molecular-genetic investigation to (1) address subspecific taxonomy, (2) characterize population genetic structure, and (3) infer past bottlenecks and demographic processes in this species. Analyses included individuals from 23 U.S. states and Canadian provinces and were based on mitochondrial DNA sequences (580 base pairs, $n=245)$ and 8 nuclear microsatellite loci $(n=229)$. Our findings provide support for separate Atlantic and Interior subspecies (C.m. melodus and C. m. circumcinctus, respectively). Birds from the Great Lakes region were allied with the Interior subspecies and should be referred to as C. m. circumcinctus. Population genetic analyses illustrated stronger genetic structure among Atlantic than among Interior birds, which may reflect reduced natal- and breeding-site fidelity of Interior individuals. Furthermore, analyses suggested that Interior birds previously experienced genetic bottlenecks, whereas there was no evidence of such patterns in the Atlantic subspecies. We interpret these results in light of 25 years of range-wide census data. Overall, differences between Interior and Atlantic Piping Plovers may reflect differences in spatiotemporal stability of nesting habitat between regions. Received 1 April 2009, accepted 20 August 2009.
\end{abstract}

Key words: bottleneck, Charadrius melodus, genetic structure, Piping Plover, population expansion, subspecies.

\section{Estatus de las Subespecies y Estructura Genética Poblacional en Charadrius melodus}

RESUMEN.-Charadrius melodus es un ave playera migratoria que se considera en peligro en Canadá y en los grandes lagos de los Estados Unidos, y amenazada en el resto de su distribución reproductiva y de invierno. Realizamos una investigación exhaustiva de genética molecular para (1) evaluar la taxonomía subespecífica, (2) caracterizar la estructura poblacional y (3) inferir cuellos de botella del pasado y procesos demográficos en esta especie. Los análisis incluyeron individuos de 23 estados de los Estados Unidos y provincias de Canadá y se basaron en secuencias de ADN mitocondrial (580 pares de bases, $n=245)$ y 8 loci microstatélites nucleares $(n=229)$. Nuestros resultados apoyan la existencia de subespecies separadas en el Atlántico y el interior (C. m. melodus y C. m. circumcinctus, respectivamente). Las aves de la región de los grandes lagos estuvieron asociadas con la subespecie del interior y deberían llamarse como C. m. circumcinctus. Los análisis de genética poblacional ilustraron la existencia de estructura genética más marcada entre las aves del Atlántico que entre las del interior, lo que podría reflejar una fidelidad reducida a los sitios natales y de reproducción por parte de los individuos del interior. Además, los análisis sugirieron que las aves del interior sufrieron cuellos de botella genéticos previamente, mientras que no existió evidencia de patrones de este tipo en la subespecie del Atlántico. Interpretamos esos resultados a la luz de datos de censos tomados a escala de toda la distribución de la especie durante 25 años. En general, las diferencias entre las aves del interior y del Atlántico podrían reflejar diferencias entre regiones en la estabilidad del hábitat de anidación en el espacio y el tiempo.

The Piping Plover (Charadrius melodus) has long been a species of conservation concern throughout its range (Fig. 1). In Canada, two subspecies are recognized: $C . m$. melodus in the Atlantic Canada region and C.m. circumcinctus in Ontario and Prairie Canada. Both subspecies are listed as endangered under the Species at Risk Act (Department of Justice Canada 2002). In the United States, Piping Plovers are listed under the Endangered

${ }^{3}$ E-mail: mpmiller@usgs.gov
Species Act (ESA) as endangered in the Great Lakes watershed and as threatened in the rest of its breeding and winter range (U.S. Fish and Wildlife Service [USFWS] 1985). The USFWS has approved separate recovery plans for populations breeding on the Atlantic Coast (USFWS 1988a, 1996), Great Lakes (USFWS 2003), and Northern Great Plains (USFWS 1988b). Primary threats include nest and chick disturbance stemming from habitat degradation

The Auk, Vol. 127, Number 1, pages 57-71. ISSN 0004-8038, electronic ISSN 1938-4254. @ 2010 by The American Ornithologists’ Union. All rights reserved. Please direct all requests for permission to photocopy or reproduce article content through the University of California Press's Rights and Permissions website, http://www.ucpressjournals. com/reprintInfo.asp. DOI: 10.1525/auk.2009.09040 


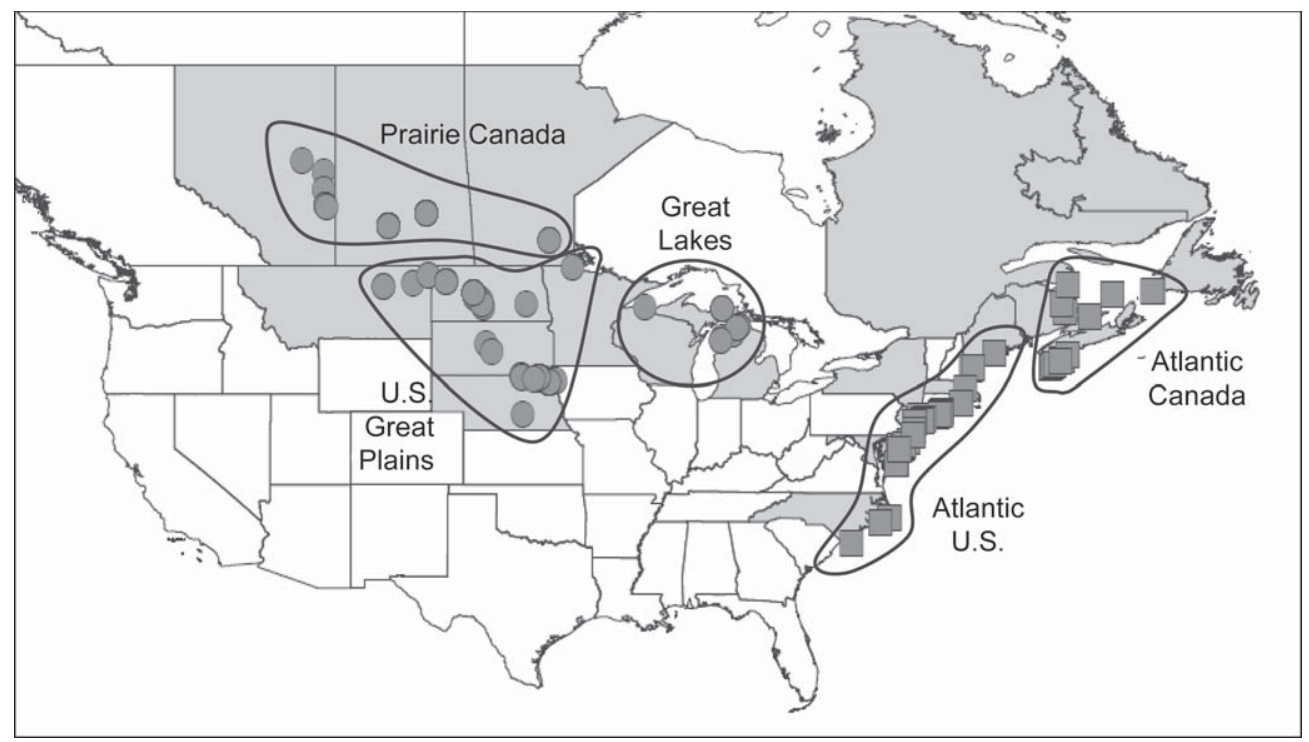

FIG. 1. Collection locations of Piping Plovers analyzed in the present study. Shaded U.S. states or Canadian provinces highlight general geographic regions. Symbols reflect specific collection locations (circles = Interior group, squares = Atlantic group). See Table 1 for regional designations and sample-size information.

associated with human land use and development practices. Predation also has been suggested as a pertinent threat (Cuthbert and Roche 2008). Complete species censuses over the past 25 years have documented range expansions, contractions, and local extirpations as well as areas where numbers have increased or decreased (Haig and Oring 1985, Haig and Plissner 1993, Plissner and Haig 2000, Haig et al. 2005, Elliott-Smith et al. 2009).

Despite continued conservation concerns, there has not been a modern molecular-genetic study to address higher-level taxonomic issues or elucidate population patterns and processes. A formal evaluation of subspecific taxonomic status is a primary need. Charadrius m. melodus (hereafter "Atlantic" subspecies) are thought to breed in the Atlantic coastal region of North America, whereas C. $m$. circumcinctus (hereafter "Interior" subspecies) have been described as breeding in the continent's interior (American Ornithologists' Union [AOU] 1957, Elliott-Smith and Haig 2004). Subspecific identification of Great Lakes birds has not been resolved, although an early allozyme study described them as belonging to the Interior subspecies (Haig and Oring 1988b). From a recovery perspective, clarifying the taxonomy of Piping Plovers may be important for informing listing and status reviews, establishing management strategies, and prioritizing funding under the ESA or the Species at Risk Act.

An understanding of taxonomy and population structure on multiple geographic and temporal scales provides critical details of a species' status and changes in status that are almost impossible to obtain without taking a molecular approach. The genetic affinity of populations is routinely used to determine the degree of vulnerability of species at risk or of population segments within species. Here, we used mitochondrial DNA (mtDNA) sequence analyses to examine taxonomic issues and provide a historical perspective on population structure in Piping Plover. We also analyzed variable microsatellite markers to provide a more recent assessment of population structure. Our analyses focused on two levels. At the primary level, we separately quantified patterns within Interior and Atlantic birds (i.e., putative subspecies). This partitioning of individuals was later substantiated by data generated in the present study (see below). Subsequent analyses also were performed at the secondary level, where data were further subdivided to reflect samples from Prairie Canada, U.S. Great Plains, Great Lakes (all Interior birds), Atlantic Canada, and Atlantic United States (all Atlantic birds) (Table 1). Although likely not pertinent from an organismal perspective, the latter set of analyses reflected geographic regions encompassed by separate U.S. and Canadian recovery plans that have been outlined for Piping Plover and, therefore, may provide a basis for informing resource managers regarding species status in their local area of charge. Taken together, these analyses provide a comprehensive assessment of population genetics for the species and serve as a basis for comparison with other measures of population status such as censuses and other demographic parameters.

\section{Methods}

Sample collection.-Following protocols outlined by the AOU (Gaunt and Oring 1997), tissue samples were collected from breeding populations throughout the Piping Plover's North American breeding range (Fig. 1). No known close relatives (parents, offspring, siblings, etc.) were included in analyses, and all samples were collected during the breeding season before birds immigrated from other sites. Specimen collection dates are provided in Appendix 1. DNA extractions were performed as described in Haig et al. (2004).

Mitochondrial sequences.-Piping Plover specific primers PPL-26L (CCCCATACTAAATTCTTAGTATGTTTGC) and PPL657H (CACGGACGAAAATGATGATATATAGC) were designed to generate a bidirectional DNA sequence of $\sim 650$ base pairs (bp) in domains I and II of the control region. Polymerase chain reactions (20 $\mu \mathrm{L}$ volume) were used with the following concentrations: $10 \mathrm{mM}$ 
TABLE 1. Collection locations and sample sizes for genetic analyses of Piping Plovers.

\begin{tabular}{|c|c|c|}
\hline Locations & $\begin{array}{c}\text { Sample size } \\
\text { (mitochondrial) }\end{array}$ & $\begin{array}{c}\text { Sample size } \\
\text { (microsatellite) }\end{array}$ \\
\hline Interior & 96 & 92 \\
\hline Prairie Canada & 29 & 27 \\
\hline Alberta & 7 & 6 \\
\hline Saskatchewan & 19 & 18 \\
\hline Manitoba & 3 & 3 \\
\hline U.S. Great Plains & 50 & 51 \\
\hline Montana & 4 & 5 \\
\hline North Dakota & 20 & 20 \\
\hline South Dakota & 19 & 20 \\
\hline Nebraska & 6 & 5 \\
\hline Minnesota & 1 & 1 \\
\hline Great Lakes & 17 & 14 \\
\hline Wisconsin & 1 & 1 \\
\hline Michigan & 16 & 13 \\
\hline Atlantic & 149 & 137 \\
\hline Atlantic Canada & 69 & 67 \\
\hline Quebec & 20 & 20 \\
\hline Newfoundland & 2 & 1 \\
\hline New Brunswick & 6 & 6 \\
\hline Prince Edward Island & 20 & 20 \\
\hline Nova Scotia & 21 & 20 \\
\hline Atlantic United States & 80 & 70 \\
\hline Maine & 6 & 6 \\
\hline Masachusetts & 1 & 2 \\
\hline Delaware & 2 & 2 \\
\hline Maryland & 17 & 16 \\
\hline Rhode Island & 3 & 2 \\
\hline New York & 20 & 19 \\
\hline New Jersey & 22 & 17 \\
\hline North Carolina & 9 & 6 \\
\hline Total & 245 & 229 \\
\hline
\end{tabular}

Tris-HClatpH 8.3;50 mMKCl; $0.001 \%$ gelatin; $3.5 \mathrm{mMMgCl}_{2} ; 100 \mu \mathrm{M}$ for each of the dNTPs; $0.2 \mu \mathrm{M}$ of each primer; $100 \mathrm{ng}$ of template; and 1.5 U AmpliTaq Gold Polymerase (Perkin Elmer, Waltham, Massachusetts). The following parameters were used for amplifications: 12 min denaturation at $93^{\circ} \mathrm{C}$, followed by 35 cycles of $30 \mathrm{~s}$ at $93^{\circ} \mathrm{C}$, annealing at $50^{\circ} \mathrm{C}$ for $30 \mathrm{~s}$, and elongation at $72^{\circ} \mathrm{C}$ for $1 \mathrm{~min}$. A final 10 -min period of elongation at $72^{\circ} \mathrm{C}$ followed the last cycle. Successful reactions were cleaned by centrifugation dialysis using Microcon 30,000 MW cutoff filters (Amicon Bioseparations, Bedford, Massachusetts). Bidirectional DNA sequence was generated with flanking primers PPL-26L and PPL-657H. Sequencing with internal primers TS-437L (Wenink et al. 1994) and PPL-493H (GGTCTTGAAGCTAGTAACGTAGGA) was also used to facilitate reads through a problematic poly-C region within the control region. Sequences were generated using ABI Prism Big Dye Terminator Cycle Sequencing chemistry on an ABI 3100 capillary DNA automated sequencer (Applied Biosystems, Foster City, California). Ambiguities were resolved by comparing light- and heavy-strand sequences or from overlap of different fragments. The final alignment contained $580 \mathrm{bp}$ of data from 245 individuals sampled in 23 U.S. states and Canadian provinces (Table 1 and Fig. 1).

Microsatellites.-Microsatellite primer sequences were obtained from several sources. Primers CALEX-8, $-13,-35$, and -37 (developed for Snowy Plover [C. alexandrinus]) were described in Küpper et al. (2007). Microsatellite locus C-201 was obtained from ISSR-suppression-PCR clone libraries (Lian et al. 2001, Funk et al. 2007). Microsatellite markers PPL-4 (F-CTGCAGTGACACAATTCCAG; R-CATCAGCTGTGGATTTGGTC), PPL-10 (F-CTGAAGACTCTGTCATCAGC; R-CATCAGTCTGATGCATCCAG), and PPL-11 (F-GACAAGGATCCGCAATATATCA; RTTACAACTTGCCAGGTCATG) were isolated using a magneticbead-capture enrichment protocol (Glenn and Schable 2005).

Sample screening PCR amplifications were performed using a total reaction volume of $10 \mu \mathrm{L}$ with the following concentrations: $10 \mathrm{mM}$ Tris- $\mathrm{HCl}$ at $\mathrm{pH} 8.3 ; 50 \mathrm{mM} \mathrm{KCl} ; 0.001 \%$ gelatin; $3.5 \mathrm{mM} \mathrm{MgCl} ; 100 \mu \mathrm{M}$ for each of the dNTPs; $0.2 \mu \mathrm{M}$ of each primer (labeled with 6-FAM or HEX); $100 \mathrm{ng}$ of template; and 1.5 U GoTaq DNA polymerase (Promega, Madison, Wisconsin). The following parameters were used for amplifications: $3 \mathrm{~min}$ denaturation at $93^{\circ} \mathrm{C}$, followed by 35 cycles of $30 \mathrm{~s}$ at $93^{\circ} \mathrm{C}$, annealing at $52^{\circ} \mathrm{C}$ (for $\mathrm{C}-201, \mathrm{PPL}-4$, PPL-10, and PPL-11) or $62^{\circ} \mathrm{C}$ (for CALEX-8, Calex-13, Calex-35, Calex-37) for $30 \mathrm{~s}$, and elongation at $72^{\circ} \mathrm{C}$ for $1 \mathrm{~min}$. A final 10 -min period of elongation at $72^{\circ} \mathrm{C}$ followed the last cycle. Amplification products were analyzed on an ABI 3100 capillary DNA automated sequencer. ABI GENESCAN ANALYSIS software was used to size fragments based on internal lane standard GeneScan 500 ROX and ABI GENOTYPER software was used to score allele sizes (Applied Biosystems). The final microsatellite data set contained genotypes from 229 individuals sampled from 23 states and provinces (Table 1 and Fig. 1).

Genetic diversity patterns.-We used the program ARLEQUIN, version 3.1 (Excoffier et al. 2005), to quantify genetic diversity measures for each geographic region. Gene and nucleotide diversity values were obtained for mitochondrial sequence data, whereas observed and expected heterozygosity values $\left(H_{\mathrm{O}}\right.$ and $H_{\mathrm{E}}$, respectively) were calculated for microsatellite data. Because of sample-size variation at the secondary level, we also used the program HP-RARE (Kalinowski 2005) to obtain rarefaction-based estimates of allelic richness that accounted for the small sample size $(n=14)$ within the Great Lakes region. At the secondary level, tests for deviations from Hardy-Weinberg genotypic proportions and for linkage disequilibrium were performed using GDA, version 1.1 (Lewis and Zaykin 2002).

Phylogenetic analyses.-Two approaches were used to characterize phylogenetic relationships among observed mitochondrial haplotypes. Initially, an appropriate model of DNA sequence evolution was identified using the program MODELGENERATOR (Keane et al. 2006) with the AIC2 model-selection measure and four gamma categories. This analysis indicated that the $\mathrm{TrN}+\mathrm{I}+\mathrm{G}$ nucleotide-substitution model was most appropriate. We performed 100 independent runs of a maximum-likelihood (ML) tree search using the program GARLI, version 0.96 (Zwickl 2006), and obtained nodal support from (1) the consensus of the 100 independent runs and (2) an additional run based on 100 bootstrap replicates. Each run was initialized with a random tree and was terminated on the basis of convergence heuristics set by two GARLI configuration parameters ("genthreshfortopoterm" =40,000; "scorethreshforterm" = 0.05). We used MRBAYES, version 3.1.2 (Ronquist and Huelsenbeck 2003), to perform Bayesian phylogenetic inference. Analyses included 4 separate runs, each containing 1 cold chain and 3 heated chains using a temperature of 0.15 . Runs were performed for $8 \times 10^{6}$ 
generations and sampled every 1,000 generations $(8,000$ sampled trees total). The first 4,000 trees were discarded as burn-in. Because MRBAYES does not implement the TrN nucleotide-substitution model, the GTR $+\mathrm{I}+\mathrm{G}$ model (a superset of the $\mathrm{TrN}+\mathrm{I}+\mathrm{G}$ model) was employed. Resulting NEWICK-formatted trees from both analysis approaches were visualized and annotated using MEGA, version 4.0 (Tamura et al. 2007).

Genetic structure analyses.-Genetic structure patterns were analyzed in several different ways. The Bayesian clustering procedure implemented in STRUCTURE, version 2.2.3 (Pritchard et al. 2000), was used to simultaneously infer the number of genetic clusters suggested by the microsatellite data and likewise probabilistically assign each analyzed individual to one of the inferred clusters. STRUCTURE analyses were performed using values of $K$ (the assumed number of clusters) ranging from 1 to 8 . Analyses were performed using an initial burn-in of $2 \times 10^{5}$ steps, followed by $1.5 \times 10^{6}$ Markov-chain Monte Carlo analysis sweeps. Default analysis options including assumption of an admixture model and correlated allele frequencies were used, as suggested by Falush et al. (2003). Ten replicates were performed using each value of $K$. Values of $K$ that produced the highest average likelihood scores over replicates were summarized and visualized using the programs CLUMPP, version 1.1.1 (Jakobsson and Rosenberg 2007), and DISTRUCT, version 1.1 (Rosenberg 2004), respectively. Independent analyses were performed for (1) the full data set and (2) separately for the subsets of Interior and Atlantic individuals to evaluate the plausibility of hierarchical genetic structure.

Data were analyzed using analysis of molecular variance (AMOVA; Excoffier et al. 1992) as implemented in ARLEQUIN. In these analyses, $\Phi_{\mathrm{ST}}$ and $F_{\mathrm{ST}}$ were calculated (for mitochondrial and microsatellite data, respectively) to quantify differentiation between the Interior and Atlantic groups and among the 5 geographic regions. Pairwise values of $\Phi_{\mathrm{ST}}$ and $F_{\mathrm{ST}}$ were also obtained for each combination of the 5 regions examined. $P$ values for all statistics were obtained using a randomization procedure based on 10,000 randomization replicates. $P$ values from pairwise tests were evaluated using sequential Bonferroni corrections. To facilitate interpretation of the pairwise comparisons, matrices of $\Phi_{\mathrm{ST}}$ and $F_{\mathrm{ST}}$ values were further analyzed using MEGA4 (Tamura et al. 2007) to generate neighbor-joining trees illustrating general patterns of dissimilarity among the 5 regions.

Mantel tests (Mantel 1967) implemented in the program ALLELES IN SPACE (Miller 2005) were used to identify correlations between genetic and geographic distances of individuals. Analyses were performed separately for mitochondrial and microsatellite data, and independent analyses were likewise performed for the Interior and Atlantic regions. For mitochondrial sequence data, inter-individual genetic distances were based on the proportion of mismatched nucleotide sites between pairs of haplotypes. Nei et al.'s (1983) genetic distance measure was used for microsatellite data. We used 10,000 randomizations to obtain $P$ values.

Inference of population history and status.-Microsatellite data were used to evaluate population status with respect to past bottleneck events using the program BOTTLENECK (Cornuet and Luikart 1996). Analyses were performed using Interior and Atlantic birds separately, as well as for each of the 5 geographic regions. Given low observed microsatellite allelic richness (see below), analyses were performed separately using a strict stepwisemutational model (SMM) and with the two-phase model (TPM) based on a TPM variance of 4 (corresponding to an average of an approximately two-step repeat motif change when nonstepwise changes occur; Di Rienzo et al. 1994) and an assumed proportion of $70 \%$ fixed SMM events. We used 10,000 simulation replicates in analyses. Excess heterozygosity compared with theoretical expectations, an indication of past bottlenecks, was evaluated using the Wilcoxon signed-rank test. Likewise, we tabulated the occurrence of distorted allele frequency distributions in different hierarchical units, which is also a useful heuristic for identifying past bottleneck events (Luikart et al. 1998).

\section{Results}

Genetic diversity patterns. - In our analyses of mitochondrial sequence variation, 70 unique haplotypes were observed among the 245 individuals examined (Appendix 2; GenBank accession nos. FJ850171-FJ850240). We detected 25 different haplotypes among the 96 Interior birds examined, whereas 49 haplotypes were identified among 149 Atlantic individuals. Only 4 haplotypes were shared between Interior and Atlantic groups. Among Interior birds, gene diversity and nucleotide diversity corresponded to 0.813 and 0.0030 , respectively. Corresponding values were higher for Atlantic birds (gene diversity: 0.917, nucleotide diversity: 0.0051). Among the 5 geographic regions, genetic diversity was highest within the Atlantic U.S. group and lowest within the Great Lakes region (Table 2).

Microsatellite markers revealed slightly different trends (Table 2). At the highest hierarchical level, $H_{\mathrm{O}}$ and $H_{\mathrm{E}}$ were higher for the

TABLE 2. Genetic diversity measures for Piping Plover mitochondrial and microsatellite data sets.

\begin{tabular}{|c|c|c|c|c|c|c|c|}
\hline \multirow[b]{2}{*}{ Subregion } & \multicolumn{3}{|c|}{ Mitochondrial } & \multicolumn{4}{|c|}{ Microsatellite } \\
\hline & $\begin{array}{l}\text { Number of } \\
\text { haplotypes }\end{array}$ & $\begin{array}{c}\text { Gene } \\
\text { diversity }\end{array}$ & $\begin{array}{c}\text { Nucleotide } \\
\text { diversity }\end{array}$ & $\begin{array}{l}\text { Average number } \\
\text { of alleles per locus }\end{array}$ & $N_{\mathrm{a}}$ & $H_{\mathrm{O}}$ & $H_{\mathrm{E}}$ \\
\hline Prairie Canada & 11 & 0.867 & 0.0039 & 2.500 & 2.410 & 0.406 & 0.410 \\
\hline U.S. Great Plains & 15 & 0.829 & 0.0028 & 2.250 & 2.200 & 0.361 & 0.386 \\
\hline Great Lakes & 7 & 0.596 & 0.0020 & 2.125 & 2.130 & 0.384 & 0.388 \\
\hline Atlantic Canada & 16 & 0.765 & 0.0032 & 1.875 & 1.700 & 0.231 & 0.221 \\
\hline Atlantic United States & 38 & 0.961 & 0.0056 & 2.250 & 2.070 & 0.248 & 0.262 \\
\hline
\end{tabular}

${ }^{a} N_{\mathrm{a}}=$ average number of alleles per locus based on rarefaction, $H_{\mathrm{O}}=$ observed heterozygosity, and $H_{\mathrm{E}}=$ expected heterozygosity. 
Interior group $\left(H_{\mathrm{O}}: 0.3930, H_{\mathrm{E}}: 0.3990\right)$ than for the Atlantic group $\left(H_{\mathrm{O}}: 0.2461, H_{\mathrm{E}}: 0.2509\right)$. Among the 5 geographic regions, diversity was highest for Prairie Canada samples and lowest for the Atlantic Canada group (Table 2). The microsatellite data were generally characterized by low allelic richness (Table 2 and Appendix 3). Among 40 tests for deviation from Hardy-Weinberg genotypic proportions, 4 significant results at the $\alpha=0.05$ level were observed: 3 from the Prairie Canada group (loci Calex-8, -37, and -35) and 1 from the U.S. Great Plains group (locus Calex-37). With the exception of locus Calex-8, which displayed slight but significant heterozygote excess in the Prairie Canada group, all other significant tests suggested heterozygote deficiencies. Five of the 140 tests for linkage disequilibrium (5 groups $\times 28$ locus pairs per group) were significant at the $\alpha=0.05$ level, a result that could be explained by chance alone.

Phylogenetic analyses.-Both phylogeny reconstruction procedures indicated differentiation of Interior and Atlantic birds. Aside from 4 shared haplotypes between regions (haplotypes 1, 2, 18, and $25)$, the remaining phylogenetic diversity was well partitioned into separable groups defined by geography (Appendix 2 and Fig. 2). Out of 100 independent ML searches, the best tree yielded a likelihood

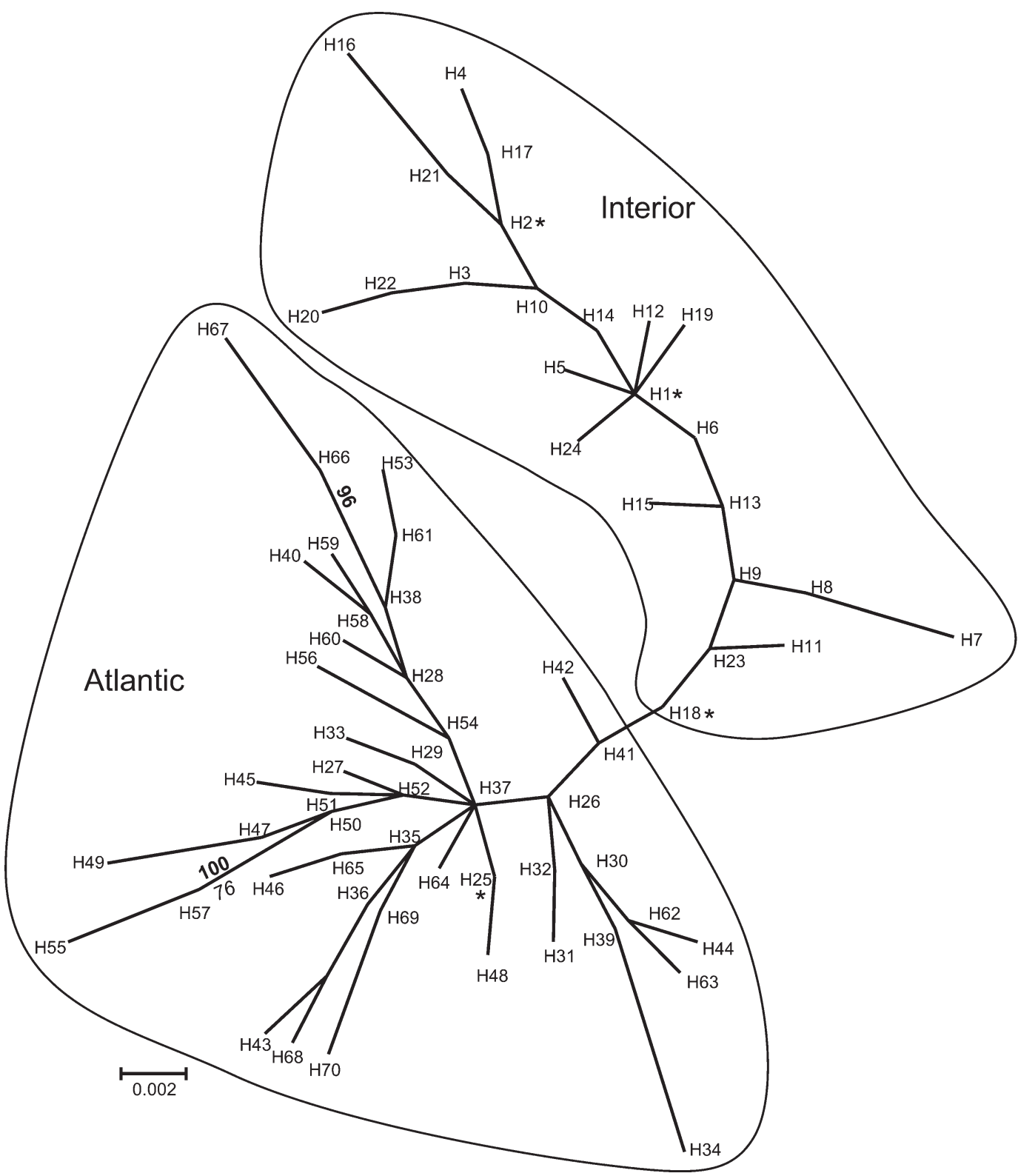

FIG. 2. Unrooted phylogram illustrating the best maximum-likelihood (ML) phylogenetic reconstruction of Piping Plover mitochondrial haplotypes. Locations where haplotypes were observed are provided in Appendix 2. Subtrees containing haplotypes found solely or mostly among Interior rather than Atlantic individuals are highlighted. Asterisks indicate 4 shared haplotypes between Interior and Atlantic birds (haplotypes 1, 2, 18, and 25). Two minor nodes with Bayesian posterior probabilities $>95 \%$ are indicated in bold, whereas the sole split with bootstrap support $>75 \%$ (from ML analyses) is indicated in italics. 

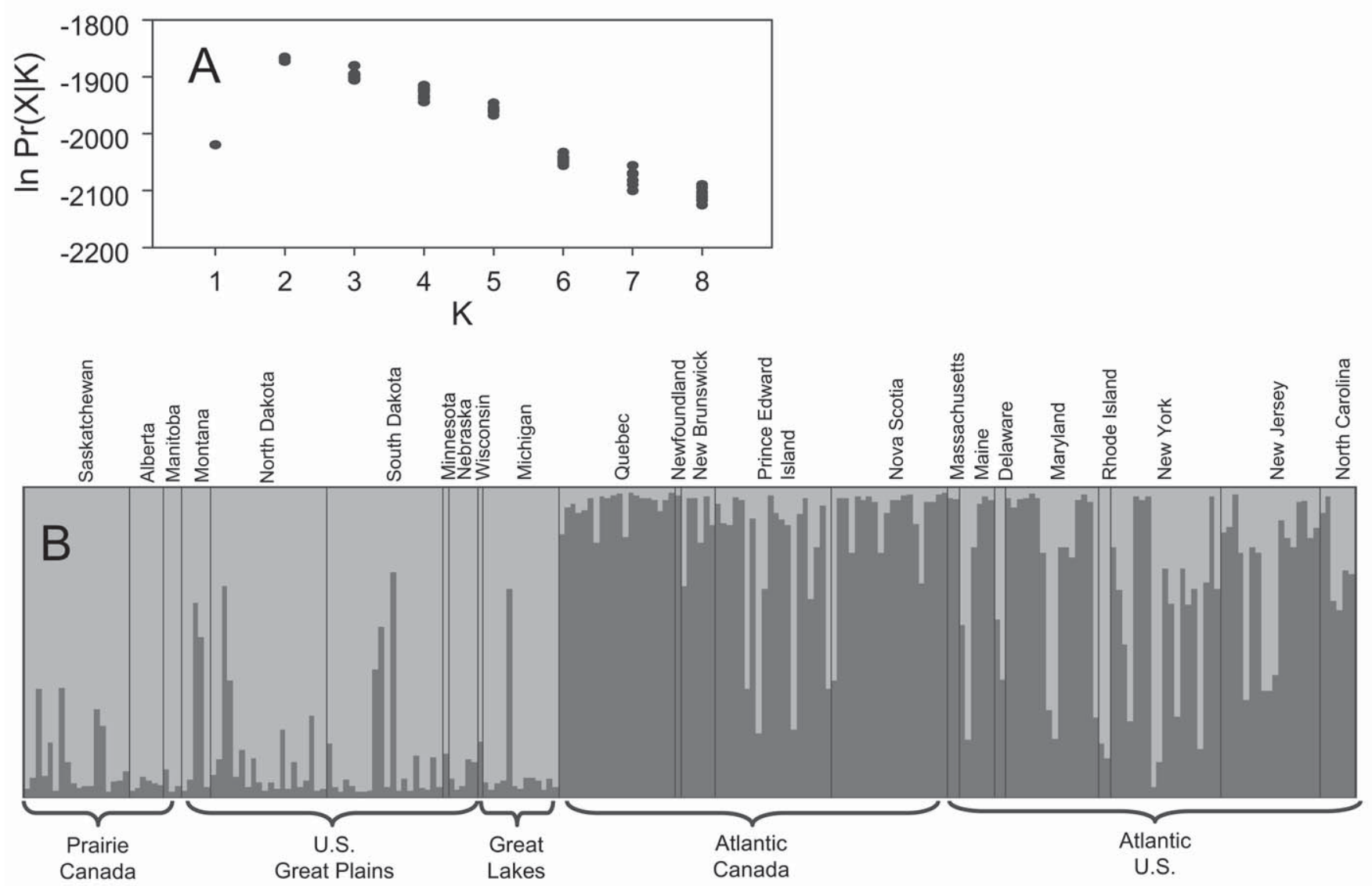

FIG. 3. Analysis in the program STRUCTURE of microsatellite data for Piping Plovers. (A) Evaluation of 10 replicate runs for values of $K$ ranging from 1 to 8 suggested that the $K=2$ solution (2 genetic clusters) was the most likely solution. (B) Individual cluster-membership coefficients suggested that genetic structure was primarily divided between the Interior and Atlantic groups.

score of $-1,293.69$. The consensus tree from these runs indicated separation of Interior and Atlantic haplotypes in 100\% of searches. The average standard deviation of split frequencies in Bayesian analyses was 0.038 , reflecting reasonable convergence of topologies over runs. The posterior probability of the Interior-Atlantic split was 0.78 , and only 2 minor nodes had posterior probabilities $>0.95$. However, ML bootstrap support for the Interior-Atlantic division was $<50 \%$, and only 1 split had nodal support $>75 \%$. The lack of bootstrap support was likely a function of the low overall divergence between groups. As evidence, haplotypes 18 and 41 (Fig. 2; closely related haplotypes from the Atlantic and Interior groups, respectively) differed by only a single nucleotide. Five of the 6 observed haplotypes observed within Great Lakes birds were allied with other haplotypes found in Interior birds (Appendix 2; haplotypes 1, 13, 15, $23,24)$. The sixth Great Lakes haplotype (haplotype 25; found in a single Great Lakes bird) was shared with a few Atlantic individuals and was part of the Atlantic haplotype group (Fig. 2).

Genetic structure analyses.-All analyses suggested strong genetic structure. STRUCTURE indicated that the most likely partitioning of the data exists for the $K=2$ case (Fig. 3A). When visualized, proportions of individual genomes assigned to each cluster suggested that the two clusters corresponded to separate Interior and Atlantic groups (Fig. 3B). Likewise, and consistent with phylogenetic analyses, individuals from the Great Lakes region (Michigan and Wisconsin) were primarily assigned to the cluster associated with Interior birds. The average cluster-membership probability of individuals was 0.877 . Of the 28 misassigned individuals (6 Interior birds and 22 Atlantic birds), none bore a mitochondrial haplotype from the opposite haplotype group. When Atlantic and Interior birds were analyzed separately, runs based on $K=1$ produced the highest average likelihood scores and suggested no additional structuring.

In comparisons of Atlantic versus Interior birds, $\Phi_{\mathrm{ST}}$ and $F_{\mathrm{ST}}$ (for mitochondrial and microsatellite data, respectively) corresponded to 0.473 and $0.104(P<0.0001)$. Likewise, $\Phi_{\mathrm{ST}}$ and $F_{\mathrm{ST}}$ values generated when data were analyzed using 5 regional groups corresponded to $0.426(P<0.0001)$ and $0.098(P<0.0001)$, respectively. Furthermore, similar patterns were observed between nuclear and mitochondrial marker data sets when comparing all pairwise values of $\Phi_{\mathrm{ST}}$ and $F_{\mathrm{ST}}$ (Fig. 4). In general, pairwise geneticdifferentiation values were smaller for contrasts within either the Interior or the Atlantic group than in between-group contrasts. Genetic distances among Interior regions were also smaller than the genetic distance between the Atlantic Canada and Atlantic United States regions. However, within the Interior region, significant $F_{\mathrm{ST}}$ values were nonetheless observed for contrasts between 


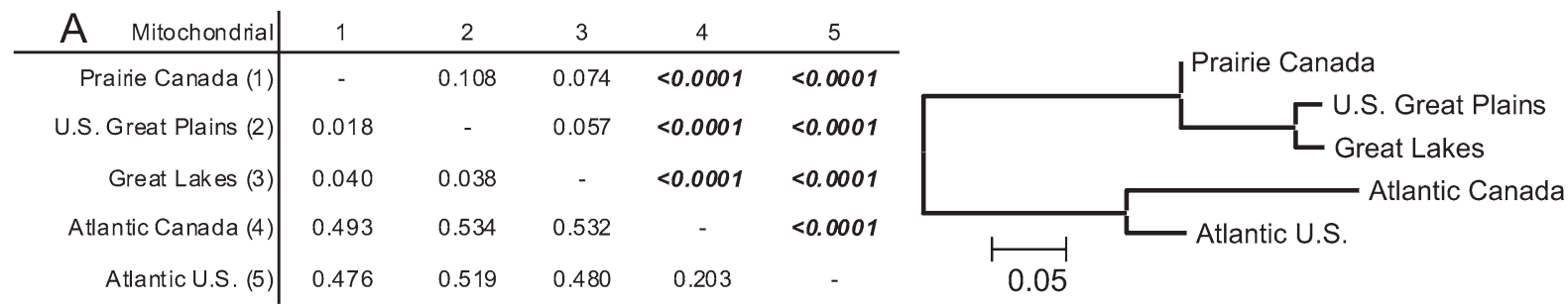

\begin{tabular}{|c|c|c|c|c|c|c|}
\hline Micros at ellite & 1 & 2 & 3 & 4 & 5 & Prairie Canada \\
\hline Prairie Canada (1) & - & 0.009 & 0.355 & $<0.0001$ & $<0.0001$ & L Great Lakes \\
\hline U.S. Great Plains (2) & 0.022 & - & 0.008 & $<0.0001$ & $<0.0001$ & L U.S. Great Plains \\
\hline Great Lakes (3) & 0.003 & 0.038 & - & $<0.0001$ & $<0.0001$ & -Atlantic Canada \\
\hline Atlantic Canada (4) & 0.151 & 0.145 & 0.174 & - & $<0.0001$ & Iantic U.S. \\
\hline Atlantic U.S. (5) & 0.121 & 0.102 & 0.117 & 0.062 & - & 0.01 \\
\hline
\end{tabular}

FIG. 4. Pairwise (A) $\Phi_{\mathrm{ST}}$ and (B) $F_{\mathrm{ST}}$ values observed from all pairwise comparisons of the 5 geographic regions examined for Piping Plovers. Actual statistics are contained within the lower off-diagonal elements, whereas congruent $P$ values are listed in the upper off-diagonal elements. Significant $P$ values after sequential Bonferroni correction are in bold italic type. Neighbor-joining trees to the right of each matrix illustrate relative dissimilarity of the regions based on the pairwise matrices.

Prairie Canada and the U.S. Great Plains and for contrasts between the Great Lakes and U.S. Great Plains (Fig. 4). Consistent with phylogenetic analyses, neighbor-joining trees generated from each matrix indicated that birds from the Great Lakes region were allied with those from the Interior region (Fig. 4).

Mantel tests gave different results for the Atlantic and Interior regions. Among Atlantic birds, significant correlations between genetic and geographic distances were observed for both mitochondrial $(r=0.237, P<0.001)$ and microsatellite $(r=0.090$, $P<0.001)$ data sets. By contrast, analyses of Interior birds revealed no such patterns (mitochondrial: $r=-0.010, P=0.54$; microsatellite: $r=0.0663, P=0.059)$.

Population history and status. - Tests for the signature of past population bottleneck events provided clear statistical patterns. All analyses performed on Interior birds and the 3 separate partitions of those data detected bottlenecks (Table 3). By contrast, no evidence of bottleneck events was identified among Atlantic individuals.

TABLE 3. Results of analyses designed to infer past bottleneck events in Piping Plovers (microsatellite data). $P$ values from tests performed using the stepwise mutational model (SMM) and two-phase model (TPM) are provided, as is an indication of whether or not shifted allele-frequency distributions were observed (consistent with bottlenecks).

\begin{tabular}{lccc}
\hline Grouping & SMM $(P)$ & TPM $(P)$ & $\begin{array}{c}\text { Shifted allele } \\
\text { frequency mode? }\end{array}$ \\
\hline All Interior & 0.027 & 0.010 & Yes \\
Prairie Canada & 0.027 & 0.010 & Yes \\
U.S. Great Plains & 0.027 & 0.010 & Yes \\
Great Lakes & 0.027 & 0.027 & Yes \\
All Atlantic & 0.594 & 0.469 & No \\
Atlantic Canada & 0.313 & 0.313 & No \\
Atlantic United States & 0.594 & 0.344 & No \\
\hline
\end{tabular}

\section{Discussion}

Subspecies status.-Previous allozyme-based genetic data (Haig and Oring 1988b) were unable to provide support for the presence of separate Interior and Atlantic subspecies that had been proposed on the basis of the geographic distribution of breast-band patterns (Moser 1942, AOU 1945). However, our use of more modern and variable genetic information systems and analyses of a substantially larger data set than Haig and Oring (1988b) revealed differentiation between Interior and Atlantic birds (Figs. 2-4). This pattern is consistent with prior field-based observations that suggested little migration of individuals between regions (Haig and Oring 1988a) and, consequently, provides evidence in support of separate Atlantic and Interior subspecies (C. m. melodus and C. m. circumcinctus, respectively; AOU 1957). Among 70 unique haplotypes detected (Appendix 2), only 4 $(5.7 \%)$ were shared between groups. If we assume that "Atlantic" haplotypes are those that were observed solely or mostly among Atlantic individuals (with the complement being true for "Interior haplotypes" and Interior birds), then $93 \%$ of Atlantic birds differ from $99 \%$ of Interior birds. This pattern exceeds the well-known " $75 \%$ rule" for defining subspecies (Amadon 1949, Patten and Unitt 2002, Haig et al. 2006). Likewise, given the large $\Phi_{\mathrm{ST}}$ and $F_{\mathrm{ST}}$ values observed between Interior and Atlantic groups (Fig. 4), our data also meet the subspecies definition of Funk et al. (2007), who defined a subspecies as

$$
\begin{aligned}
& \text { a subset of populations with consistent genetic differences } \\
& \text { from other subsets of populations at multiple independent } \\
& \text { loci, with genetic differences consisting of significant vari- } \\
& \text { ation in microsatellite allele and mtDNA haplotype fre- } \\
& \text { quencies, the presence of unique alleles or haplotypes, and } \\
& \text { significant net sequence divergence. }
\end{aligned}
$$

Our data also illustrated that birds from the Great Lakes region are allied with the Interior group and should be taxonomically referred to as C. m. circumcinctus. Note that genetic evidence for 
two Piping Plover subspecies contrasts with weak genetic differentiation among U.S. Snowy Plovers (Funk et al. 2007). Given the observed differentiation between C. m. melodus and C. m. circum cinctus, we suggest that future research evaluating adaptive divergence or reproductive isolation of subspecies may be informative.

Regional genetic structure.-Results of genetic structure analyses obtained from STRUCTURE were inconsistent with those produced by conventional analyses based on allele frequencies. The former indicated that $K=1$ was most likely within each region; however, the latter suggested that different patterns of genetic structure exist within each subspecies. This difference is likely attributable to the presence of weak (but significant) genetic structure or underlying isolation-by-distance patterns, neither of which is easily detected by STRUCTURE (see sections 4.4 and 4.5 of STRUCTURE documentation; Latch et al. 2006, Schwartz and McKelvey 2009).

Within the Interior group, pairwise $\Phi_{\mathrm{ST}}$ and $F_{\mathrm{ST}}$ values were markedly lower than comparable values generated for contrasts between Atlantic Canada and the Atlantic United States (Fig. 4). This pattern may reflect higher individual gene flow (reduced breedingsite fidelity) in Interior birds than in Atlantic birds. However, despite producing lower pairwise values, significant $F_{\mathrm{ST}}$ values were nonetheless observed in the Interior region for 2 of the 3 pairwise contrasts based on microsatellite data (Fig. 4). This result suggests that the Interior subspecies does not represent a single panmictic entity. Field observations appear to corroborate this idea, in that $>20$ years of bird-banding studies have never identified Great Lakes birds breeding west of Lake Superior (or vice versa) (J. Dingledine, USFWS, and F. Cuthbert, University of Minnesota, pers. comm.). Consequently, long-distance gene flow, when it occurs, may be episodic and insufficient to maintain demographic connectivity of regions.

Spatial genetic-structure patterns were also in agreement with pairwise $\Phi_{\mathrm{ST}}$ and $F_{\mathrm{ST}}$ values, in that Atlantic birds showed evidence of isolation-by-distance patterns. In this case, our data suggest that dispersal, when it occurs, is generally associated with movement to relatively proximal breeding territories. By contrast, Interior birds showed no overt spatial genetic-structure signals. This pattern is consistent with the reduced genetic differentiation among Interior subregions (Fig. 4) and may reflect reduced breeding-site or natalsite fidelity when previously occupied sites are unavailable because they are flooded, dry, overgrown with vegetation, or otherwise disturbed by human activities. Overall, differences between Interior and Atlantic birds may reflect regional variation in habitat stability. Atlantic regions may provide more reliable, long-term habitat for Piping Plovers that is less likely to demonstrate extreme spatiotemporal variability. By contrast, the Interior region of North America experiences substantial temporal climatic variation that may cause flooding or complete desiccation of alkali lakes and other wetlands (Espie et al. 1998, Haig et al. 2005). Furthermore, humancontrolled variable flooding regimes on the Missouri River may periodically force dispersal of many birds nesting in the Great Plains if habitat becomes unavailable because of inundation, vegetation encroachment, or other habitat disturbances (North 1986; Schwalbach et al. 1993, as cited in Espie et al. 1998).

Genetic diversity, population status, and history.-Piping Plover genetic diversity appeared to be comparable to the range of values observed in two Snowy Plover subspecies from the continental
U.S. and Caribbean (Funk et al. 2007). Snowy Plover is a species of conservation concern, although only one Distinct Population Segment is ESA-listed (USFWS 1993). In our analyses, mitochondrial control-region nucleotide diversity (Table 2 ) ranged from 0.0020 to 0.0056 (mean $=0.0044$ ) compared with a range of 0.0006 to 0.0083 at the same locus in Snowy Plover (mean $=0.0042)$. Average expected microsatellite heterozygosity within each region ( $\mathrm{Ta}$ ble 2; range: $0.2211-0.4098$, mean $=0.3334$ ) likewise fell within the range of values in Snowy Plover (range: 0.249-0.539, mean = 0.453). The slightly higher average value in Snowy Plover likely reflects differences in allelic richness of the microsatellite loci investigated in the present study and by Funk et al. (2007). Among 8 microsatellite loci examined here, numbers of alleles ranged from 2 to 5 (mean $=2.875)$ across our full data set. By contrast, an average of 4.8 alleles per locus (range: $2-10$ ) were present among the 10 loci examined by Funk et al. (2007).

Our evaluations of population status and history suggested differences between Interior and Atlantic Piping Plovers (Table 3), which is consistent with our phylogenetic and genetic-structure analyses. The microsatellite data indicated that each of the $3 \mathrm{In}$ terior subregions (and all Interior birds combined) showed evidence of past genetic bottlenecks, whereas no such patterns were observed among Atlantic birds. Note that tests based on the SMM tend to be highly conservative compared with those based on the TPM (Cornuet and Luikart 1996). Consequently, the significance of both SMM- and TPM-based analyses, coupled with the heuristics provided by observed allele-frequency distribution shifts, provide compelling evidence for past bottlenecks within the Interior region.

The timing and intensity of influential historical events can be difficult to infer solely on the basis of genetic data. For example, detection of bottlenecks depends on the interplay of a multivariate combination of statistical and population parameters that primarily include (1) size of the pre-bottleneck population, (2) size of the post-bottleneck population, (3) duration of the bottleneck event, (4) number of sampled individuals for analyses, and (5) number of loci examined (Cornuet and Luikart 1996, Luikart et al. 1998). Historical records and prior census data (Haig and Oring 1985, Haig and Plissner 1993, Plissner and Haig 2000, Haig et al. 2005, Elliott-Smith et al. 2009), however, tend to corroborate the general inferences provided by our analyses. For example, in the mid-1980s, it was estimated that $<2,000$ Piping Plover breeding pairs existed in North America (Haig and Oring 1985), only $\sim 17$ of which inhabited the Great Lakes region (USFWS 1985, Haig and Oring 1988a). These estimates are thought to reflect severe population declines that began in the early 20th century (Haig and Oring 1985, 1988a) and likely resulted in the significant bottleneck events we detected among Interior birds in general. However, available data do not allow us to provide more explicit temporal estimates, nor do they allow us to determine whether the same (or different) bottleneck events influenced all Interior regions. That said, data from 4 international censuses over 15 years suggest that population increases have occurred among Interior birds in recent decades. For example, between 1991 and 2006, the number of birds counted in the Great Lakes increased by 175\% (from 40 to 110 birds; Haig and Plissner 1993, Haig and Elliott-Smith et al. 2009). Comparable trends have been observed in Prairie Canada and the U.S. Great Plains, where census data also indicated recent increases in population size (3,467 birds in 1991 vs. 4,662 in 2006; Haig and Plissner 
1993, Elliott-Smith et al. 2009). Combined, this information may indicate population increases that followed prior bottleneck events within the Interior region.

In contrast to Interior birds, Atlantic populations exhibited no evidence of genetic bottlenecks. If our hypothesis regarding the relative stability of Atlantic versus Interior habitats is correct, Atlantic birds may not have experienced historical population reductions or bottlenecks of the magnitude experienced by Interior birds. As evidence, census data (Haig and Plissner 1993, Elliott-Smith et al. 2009) indicate that the Atlantic Canada population has changed little from 1991 to 2006 (513 birds in 1991 and 457 in 2006), which suggests relatively stable current population sizes. However, the Atlantic U.S. population appears to have almost doubled in size in recent years (1,462 birds were observed in 1991 and 2,828 in 2006 Haig and Plissner 1993, Elliott-Smith et al. 2009). Absence of a consistent bottleneck signal in this case may indicate a normal population-growth trajectory that was not preceeded by a prior reduction in population size. Alternatively, if a bottleneck actually has occurred within the region, it was apparently not of sufficient magnitude and duration or not in the right time frame to be detected, given the sampling effort (numbers of individuals and loci) encompassed by our study.

\section{ACKNOWLEDGMENTS}

We thank the U.S. Geological Survey (USGS) Forest and Rangeland Ecosystem Science Center (FRESC) and Environment Canada for funding this study. We are further thankful for discussions with and comments by E. Elliott-Smith (USGS, FRESC) and A. Hecht (U.S. Fish and Wildlife Service). Many people have contributed invaluable samples to this project, and we are deeply grateful for their assistance: I. Ailes, D. Amirault, S. Brennan, S. Canale, J. Cordes, F. Cuthbert, J. Dare, B. Dirks, N. Dufef, J. Fung, N. Gibbons, K. Gordon, R. Gough, A. Joa, K. Johnson, C. Kruse, M. Lyons, J. McArthur, S. McBurney, E. McMichaels, A. Nichols, G. Pavelka, R. Perez, S. Philhower, R. Powell, N. Olenych, A. Orgonik, P. Railey, S. Ramsey, C. Roy, F. Shaffer, J. Sidle, J. Stucker, G. Venaton, G. Warrick, S. Welte, and T. Zadi.

\section{Literature Cited}

Amadon, D. 1949. The seventy-five per cent rule for subspecies. Condor 51:250-258.

American Ornithologists' Union. 1945. Twentieth supplement to the American Ornithologists' Union Check-list of North American Birds. Auk 62:436-449.

American Ornithologists' Union. 1957. Check-list of North American Birds, 5th ed. American Ornithologists' Union, Washington, D.C.

Cornuet, J. M., and G. Luikart. 1996. Description and power analysis of two tests for detecting recent population bottlenecks from allele frequency data. Genetics 144:2001-2014.

Cuthbert, F. J., And E. A. Roche. 2008. The Piping Plover in Michigan: A 100 year perspective. Michigan Birds and Natural History 15:29-38.

Department of Justice Canada. 2002. Annual Statutes of Canada 2002, Chapter 29, Species at Risk Act, Schedule 1, Part 2. [Online.] Available at www.canlii.org/en/ca/laws/stat/sc-2002c-29/latest/.
Di Rienzo, A., A. C. Peterson, J. C. Garza, A. M. Valdes, M. Slatkin, ANd N. B. Freimer. 1994. Mutational processes of simple-sequence repeat loci in human populations. Proceedings of the National Academy of Sciences USA 91:3166-3170.

Elliott-Smith, E., and S. M. Haig. 2004. Piping Plover (Charadrius melodus). In The Birds of North America Online (A. Poole, Ed.). Cornell Lab of Ornithology, Ithaca, New York. [Online.] Available at bna.birds.cornell.edu/bna/species/002.

Elliott-Smith, E., S. M. Haig, and B. M. Powers. 2009. Data from the 2006 International Piping Plover Census. U.S. Geological Survey Data Series 426.

Espie, R. H. M., P. C. James, ANd R. M. BRigham. 1998. The effects of flooding on Piping Plover Charadrius melodus reproductive success at Lake Diefenbaker, Saskatchewan, Canada. Biological Conservation 86:215-222.

Excoffier, L., G. LAVAL, AND S. SCHNEIDER. 2005. ARLEQUIN (version 3.0): An integrated software package for population genetics data analysis. Evolutionary Bioinformatics Online 1:47-50.

EXCOFfier, L., P. E. SMOUSE, AND J. M. QuATtro. 1992. Analysis of molecular variance inferred from metric distances among DNA haplotypes: Application to human mitochondrial DNA restriction data. Genetics 131:479-491.

Falush, D., M. Stephens, and J. K. Pritchard. 2003. Inference of population structure using multilocus genotype data: Linked loci and correlated allele frequencies. Genetics 164:1567-1587.

FunK, W. C., T. D. Mullins, and S. M. Haig. 2007. Conservation genetics of Snowy Plovers (Charadrius alexandrinus) in the Western Hemisphere: Population genetic structure and delineation of subspecies. Conservation Genetics 8:1287-1309.

Gaunt, A. S., AND L. W. Oring, EDs. 1997. Guidelines to the Use of Wild Birds in Research. Ornithological Council, Washington, D.C.

GlenN, T. C., AND N. A. SChable. 2005. Isolating microsatellite DNA loci. Methods in Enzymology 395:202-222.

Haig, S. M., E. A. Beever, S. M. Chambers, H. M. Draheim, B. D. Dugger, S. Dunham, E. Elliott-Smith, J. B. Fontaine, D. C. Kesler, B. J. Knaus, And others. 2006. Taxonomic considerations in listing subspecies under the U.S. Endangered Species Act. Conservation Biology 20:1584-1594.

Haig, S. M., C. L. Ferland, F. J. Cuthbert, J. Dingledine, J. P. Goossen, A. Hecht, And N. McPhillips. 2005. A complete species census and evidence for regional declines in Piping Plovers. Journal of Wildlife Management 69:160-173.

Haig, S. M., T. D. Mullins, and E. D. Forsman. 2004. Subspecific relationships and genetic structure in the Spotted Owl. Conservation Genetics 5:683-705.

HAIG, S. M., AND L. W. ORING. 1985. Distribution and status of the Piping Plover throughout the annual cycle. Journal of Field Ornithology 56:334-345.

HaIG, S. M., AND L. W. OrING. 1988a. Distribution and dispersal in the Piping Plover. Auk 105:630-638.

Haig, S. M., AND L. W. OrING. 1988b. Genetic differentiation of Piping Plovers across North America. Auk 105:260-267.

Haig, S. M., AND J. H. Plissner. 1993. Distribution and abundance of Piping Plovers: Results and implications of the 1991 international census. Condor 95:145-156.

Jakobsson, M., and N. A. Rosenberg. 2007. CLUMPP: A cluster matching and permutation program for dealing with label 
switching and multimodality in analysis of population structure. Bioinformatics 23:1801-1806.

KALINOWSKI, S. T. 2005. HP-Rare 1.0: A computer program for performing rarefaction on measures of allelic richness. Molecular Ecology Notes 5:187-189.

Keane, T. M., C. J. Creevey, M. M. Pentony, T. J. Naughton, AND J. O. MCInerney. 2006. Assessment of methods for amino acid matrix selection and their use on empirical data shows that ad hoc assumptions for choice of matrix are not justified. BMC Evolutionary Biology 6:29.

Küpper, C., G. J. Horsburgh, D. A. Dawson, R. FfrenchConstant, T. SzéKely, AND T. BurKe. 2007. Characterization of 36 polymorphic microsatellite loci in the Kentish plover (Charadrius alexandrinus) including two sex-linked loci and their amplification in four other Charadrius species. Molecular Ecology Notes 7:35-39.

Latch, E. K., G. Dharmarajan, J. C. Glaubitz, and O. E. RHODES, JR. 2006. Relative performance of Bayesian clustering software for inferring population substructure and individual assignment at low levels of population differentiation. Conservation Genetics 7:295-302.

Lewis, P. O., AND D. ZayKIn. 2002. GDA: Genetic Data Analysis. [Computer software distributed by authors.] [Online.] Available at hydrodictyon.eeb.uconn.edu/people/plewis/software.php.

Lian, C., Z. Zhou, and T. Hogetsu. 2001. A simple method for developing microsatellite markers using amplified fragments of inter-simple sequence repeat (ISSR). Journal of Plant Research 114:381-385

Luikart, G., F. W. Allendorf, J. M. Cornuet, And W. B. SherWIN. 1998. Distortion of allele frequency distributions provides a test for recent population bottlenecks. Journal of Heredity 89:238-247.

MANTEL, N. 1967. The detection of disease clustering and a generalized regression approach. Cancer Research 27:209-220.

MilleR, M. P. 2005. Alleles in Space (AIS): Computer software for the joint analysis of interindividual spatial and genetic structure. Journal of Heredity 96:722-724.

Moser, R. A. 1942. Should the Belted Piping Plover be recognized as a valid race? Nebraska Bird Review 10:31-37.

Nei, M., F. Tajima, AND Y. Tateno. 1983. Accuracy of estimated phylogenetic trees from molecular data. II. Gene frequency data. Journal of Molecular Evolution 19:153-170.

NorTh, M. R. 1986. Piping Plover nest successs on Mallard Island in North Dakota and implications for water level management. Prairie Naturalist 18:117-122.

Patten, M. A., And P. Unitt. 2002. Diagnosability versus mean differences of Sage Sparrow subspecies. Auk 119:26-35.

Plissner, J. H., AND S. M. Haig. 2000. Status of a broadly distributed endangered species: Results and implications of the second international Piping Plover census. Canadian Journal of Zoology 78:128-139.
Pritchard, J. K., M. Stephens, and P. Donnelly. 2000. Inference of population structure using multilocus genotype data. Genetics 155:945-959.

RonQuist, F., AND J. P. HuelsenbeCK. 2003. MRBAYES 3: Bayesian phylogenetic inference under mixed models. Bioinformatics 19:1572-1574.

RosenberG, N. A. 2004. DISTRUCT: A program for the graphical display of population structure. Molecular Ecology Notes 4:137-138

Schwalbach, M. J., K. F. Higgins, J. Dinan, B. J. Dirks, and C. D. KRUSE. 1993. Effects of water levels on interior Least Tern and Piping Plover nesting along the Missouri river in South Dakota. Pages 75-81 in Proceedings, the Missouri River and Its Tributaries: Piping Plover and Least Tern Symposium (K. F. Higgins and M. R. Brashier, Eds.). South Dakota State University, Brookings.

Schwartz, M. K., And K. S. McKelvey. 2009. Why sampling scheme matters: The effect of sampling scheme on landscape genetic results. Conservation Genetics 10:441-452.

Tamura, K., J. Dudley, M. Nei, and S. Kumar. 2007. MEGA4 Molecular Evolutionary Genetics Analysis (MEGA) software version 4.0. Molecular Biology and Evolution 24:1596-1599.

U.S. Fish AND Wildlife Service. 1985. Determination of endangered and threatened status for the Piping Plover. Federal Register 50:50726-50734.

U.S. Fish and Wildlife Service. 1988a. Atlantic Coast Piping Plover Recovery Plan. U.S. Fish and Wildlife Service, Newton Corner, Massachusetts.

U.S. Fish ANd Wildlife Service. 1988b. Great Lakes and Northern Great Plains Piping Plover Recovery Plan. U.S. Fish and Wildlife Service, Twin Cities, Minnesota.

U.S. Fish ANd Wildlife SERVice. 1993. Determination of threatened status for the Pacific Coast population of the Western Snowy Plover. Federal Register 58:12864-12874.

U.S. Fish AND Wildlife Service. 1996. Piping Plover (Charadrius melodus) Atlantic Coast Population: Revised Recovery Plan. U.S. Fish and Wildlife Service, Hadley, Massachusetts.

U.S. Fish AND WILDLIFE SERVICE. 2003. Recovery Plan for the Great Lakes Piping Plover (Charadrius melodus). U.S. Fish and Wildlife Service, Fort Snelling, Minnesota.

Wenink, P. W., A. J. Baker, and M. G. J. Tilanus. 1994. Mitochondrial control-region sequences in two shorebird species, the Turnstone and the Dunlin, and their utility in population genetic studies. Molecular Biology and Evolution 11:22-31.

ZwiCKL, D. J. 2006. Genetic algorithm approaches for the phylogenetic analysis of large biological sequence datasets under the maximum likelihood criterion. Ph.D. dissertation, University of Texas, Austin.

Associate Editor: R. T. Brumfield 
APPENDIX 1. Collection years and U.S. state or Canadian province of each individual used in either mitochondrial or microsatellite analyses ( $y=y e s$, $\mathrm{n}=\mathrm{no})$. Collection years are unknown for 15 Piping Plover specimens included here.

\begin{tabular}{|c|c|c|c|c|c|c|c|c|c|}
\hline $\begin{array}{l}\text { Genetic } \\
\text { sample ID }\end{array}$ & $\begin{array}{l}\text { Mitochondrial } \\
\text { data }\end{array}$ & $\begin{array}{c}\text { Microsatellite } \\
\text { data }\end{array}$ & $\begin{array}{c}\text { Year } \\
\text { collected }\end{array}$ & $\begin{array}{l}\text { State or } \\
\text { province }\end{array}$ & $\begin{array}{l}\text { Genetic } \\
\text { sample ID }\end{array}$ & $\begin{array}{l}\text { Mitochondrial } \\
\text { data }\end{array}$ & $\begin{array}{l}\text { Microsatellite } \\
\text { data }\end{array}$ & $\begin{array}{c}\text { Year } \\
\text { collected }\end{array}$ & $\begin{array}{l}\text { State or } \\
\text { province }\end{array}$ \\
\hline SK1 & y & $y$ & 1997 & Saskatchewan & ND18 & y & y & 1995 & North Dakota \\
\hline SK2 & y & y & 1997 & Saskatchewan & ND19 & y & y & 1995 & North Dakota \\
\hline SK 3 & $y$ & $y$ & 1997 & Saskatchewan & ND20 & y & y & 1995 & North Dakota \\
\hline SK4 & y & y & 1997 & Saskatchewan & SD1 & y & $\mathrm{n}$ & 1993 & South Dakota \\
\hline SK5 & y & $n$ & 2002 & Saskatchewan & SD2 & y & $y$ & 1988 & South Dakota \\
\hline SK6 & y & y & 2002 & Saskatchewan & SD3 & y & n & 1988 & South Dakota \\
\hline SK7 & y & $y$ & 2002 & Saskatchewan & SD4 & $y$ & $y$ & 1988 & South Dakota \\
\hline SK8 & y & y & 2002 & Saskatchewan & SD5 & y & y & 1988 & South Dakota \\
\hline SK9 & y & y & 2002 & Saskatchewan & SD6 & $y$ & $y$ & 1988 & South Dakota \\
\hline SK10 & y & y & 2002 & Saskatchewan & SD7 & y & y & - & South Dakota \\
\hline SK11 & y & y & 2002 & Saskatchewan & SD8 & y & y & 1995 & South Dakota \\
\hline SK12 & y & y & 2002 & Saskatchewan & SD9 & y & y & 1995 & South Dakota \\
\hline SK13 & $y$ & y & 2002 & Saskatchewan & SD10 & $y$ & $n$ & 1995 & South Dakota \\
\hline SK14 & y & y & 2002 & Saskatchewan & SD11 & y & $\mathrm{n}$ & 1995 & South Dakota \\
\hline SK15 & $y$ & $y$ & 2002 & Saskatchewan & SD12 & $y$ & $y$ & 1995 & South Dakota \\
\hline SK16 & y & y & 2001 & Saskatchewan & SD13 & y & n & 1995 & South Dakota \\
\hline SK17 & y & y & 2002 & Saskatchewan & SD14 & y & $\mathrm{n}$ & 1995 & South Dakota \\
\hline SK18 & y & y & 2002 & Saskatchewan & SD15 & $y$ & $\mathrm{n}$ & 1995 & South Dakota \\
\hline SK19 & y & y & 2002 & Saskatchewan & SD16 & y & $\mathrm{n}$ & 1995 & South Dakota \\
\hline AB1 & $y$ & $y$ & 2001 & Alberta & SD17 & y & $y$ & 1996 & South Dakota \\
\hline AB2 & $y$ & y & 2001 & Alberta & SD18 & $y$ & $y$ & - & South Dakota \\
\hline AB3 & $y$ & $y$ & 2001 & Alberta & SD19 & $\mathrm{n}$ & $y$ & - & South Dakota \\
\hline AB4 & $y$ & $y$ & 2001 & Alberta & SD20 & $y$ & y & 1996 & South Dakota \\
\hline AB5 & $y$ & $\mathrm{n}$ & 2001 & Alberta & SD21 & $n$ & $y$ & 1994 & South Dakota \\
\hline AB6 & $y$ & $y$ & 2001 & Alberta & SD22 & $n$ & y & 1994 & South Dakota \\
\hline AB7 & y & y & 2001 & Alberta & SD23 & $n$ & y & 1994 & South Dakota \\
\hline MB1 & y & y & 1999 & Manitoba & SD24 & $\mathrm{n}$ & y & 1994 & South Dakota \\
\hline MB2 & y & y & 2000 & Manitoba & SD25 & $n$ & y & 1994 & South Dakota \\
\hline MB3 & $y$ & y & 2000 & Manitoba & SD26 & $n$ & $y$ & 1994 & South Dakota \\
\hline MT1 & $y$ & y & 1995 & Montana & SD27 & $n$ & y & 1994 & South Dakota \\
\hline MT2 & y & y & 1995 & Montana & SD28 & $n$ & y & 1994 & South Dakota \\
\hline MT3 & y & y & 1995 & Montana & MN1 & y & y & 1994 & Minnesota \\
\hline MT4 & $y$ & y & 2008 & Montana & WI1 & y & y & 2001 & Wisconsin \\
\hline MT5 & $y$ & $y$ & 2008 & Montana & MI1 & y & $\mathrm{n}$ & 1991 & Michigan \\
\hline NE1 & $y$ & y & - & Nebraska & MI2 & y & y & 1993 & Michigan \\
\hline NE2 & y & y & - & Nebraska & MI3 & $y$ & $y$ & 1993 & Michigan \\
\hline NE3 & y & y & - & Nebraska & MI4 & $y$ & $y$ & 1994 & Michigan \\
\hline NE4 & $y$ & $y$ & 1996 & Nebraska & MI5 & y & $y$ & - & Michigan \\
\hline NE5 & $y$ & $y$ & - & Nebraska & MI6 & y & y & 1999 & Michigan \\
\hline NE19 & y & $n$ & 1996 & Nebraska & MI7 & $y$ & y & 1999 & Michigan \\
\hline ND1 & $y$ & $y$ & 1995 & North Dakota & MI8 & $y$ & $n$ & 1999 & Michigan \\
\hline ND2 & y & y & 1994 & North Dakota & MI9 & y & y & 1992 & Michigan \\
\hline ND3 & $y$ & y & 1992 & North Dakota & MI10 & y & y & - & Michigan \\
\hline ND4 & $y$ & $y$ & 1993 & North Dakota & Ml11 & y & y & - & Michigan \\
\hline ND5 & y & y & 1995 & North Dakota & MI12 & y & y & - & Michigan \\
\hline ND6 & $y$ & y & 1995 & North Dakota & MI13 & y & y & 1994 & Michigan \\
\hline ND7 & y & y & 1995 & North Dakota & MI14 & y & $n$ & 1992 & Michigan \\
\hline ND8 & y & y & 1995 & North Dakota & MI15 & y & y & 1992 & Michigan \\
\hline ND9 & y & y & 1995 & North Dakota & MI16 & $y$ & y & 2001 & Michigan \\
\hline ND10 & $y$ & y & 1995 & North Dakota & NS1 & y & y & 2001 & Nova Scotia \\
\hline ND11 & $y$ & $y$ & 1995 & North Dakota & NS2 & y & $y$ & 2002 & Nova Scotia \\
\hline ND12 & $y$ & $y$ & 1995 & North Dakota & NS3 & y & y & 2002 & Nova Scotia \\
\hline ND13 & y & y & 1996 & North Dakota & NS4 & y & $\mathrm{n}$ & 2003 & Nova Scotia \\
\hline ND14 & $y$ & $y$ & 1995 & North Dakota & NS5 & $y$ & $y$ & 2003 & Nova Scotia \\
\hline ND15 & $y$ & y & 1995 & North Dakota & NS6 & y & $y$ & 2000 & Nova Scotia \\
\hline ND16 & $y$ & y & 1995 & North Dakota & NS7 & y & $n$ & 2001 & Nova Scotia \\
\hline ND17 & $y$ & $y$ & 1995 & North Dakota & NS8 & y & $\mathrm{n}$ & 2004 & Nova Scotia \\
\hline
\end{tabular}


APPENDIX 1. Continued.

\begin{tabular}{|c|c|c|c|c|c|c|c|c|c|}
\hline $\begin{array}{l}\text { Genetic } \\
\text { sample ID }\end{array}$ & $\begin{array}{l}\text { Mitochondrial } \\
\text { data }\end{array}$ & $\begin{array}{c}\text { Microsatellite } \\
\text { data }\end{array}$ & $\begin{array}{c}\text { Year } \\
\text { collected }\end{array}$ & $\begin{array}{l}\text { State or } \\
\text { province }\end{array}$ & $\begin{array}{l}\text { Genetic } \\
\text { sample ID }\end{array}$ & $\begin{array}{l}\text { Mitochondrial } \\
\text { data }\end{array}$ & $\begin{array}{c}\text { Microsatellite } \\
\text { data }\end{array}$ & $\begin{array}{c}\text { Year } \\
\text { collected }\end{array}$ & $\begin{array}{l}\text { State or } \\
\text { province }\end{array}$ \\
\hline NS9 & y & y & 2000 & Nova Scotia & \multirow[t]{2}{*}{ PEI18 } & \multirow[t]{2}{*}{ y } & \multirow[t]{2}{*}{ y } & \multirow[t]{2}{*}{1994} & \multirow{2}{*}{$\begin{array}{c}\text { Prince Edward } \\
\text { Island }\end{array}$} \\
\hline NS10 & $y$ & y & 2002 & Nova Scotia & & & & & \\
\hline NS11 & y & y & 2002 & Nova Scotia & \multirow[t]{2}{*}{ PEl19 } & \multirow[t]{2}{*}{ y } & \multirow[t]{2}{*}{ y } & \multirow[t]{2}{*}{1994} & \multirow{2}{*}{$\begin{array}{c}\text { Prince Edward } \\
\text { Island }\end{array}$} \\
\hline NS12 & y & y & 2002 & Nova Scotia & & & & & \\
\hline NS13 & y & $\mathrm{n}$ & 2003 & Nova Scotia & \multirow[t]{2}{*}{ PEI20 } & \multirow[t]{2}{*}{ y } & \multirow[t]{2}{*}{ y } & \multirow[t]{2}{*}{2005} & \multirow{2}{*}{$\begin{array}{c}\text { Prince Edward } \\
\text { Island }\end{array}$} \\
\hline NS14 & y & y & 2000 & Nova Scotia & & & & & \\
\hline NS15 & y & y & 2003 & Nova Scotia & QB1 & y & y & 1995 & Quebec \\
\hline NS16 & y & y & 2003 & Nova Scotia & QB2 & y & y & 1995 & Quebec \\
\hline NS17 & y & y & 2004 & Nova Scotia & QB3 & y & y & 1995 & Quebec \\
\hline NS18 & $y$ & y & 2004 & Nova Scotia & QB4 & y & y & 1995 & Quebec \\
\hline NS19 & $y$ & y & 2003 & Nova Scotia & QB5 & y & y & 1995 & Quebec \\
\hline NS20 & y & y & 2003 & Nova Scotia & QB6 & y & y & 1995 & Quebec \\
\hline NS21 & y & y & 2004 & Nova Scotia & QB7 & $\begin{array}{l}y \\
y\end{array}$ & y & 1995 & Quebec \\
\hline NS22 & $\mathrm{n}$ & y & 2004 & Nova Scotia & QB8 & y & y & 1995 & Quebec \\
\hline NS23 & $\mathrm{n}$ & y & 2004 & Nova Scotia & QB9 & y & y & 1995 & Quebec \\
\hline NS26 & $\mathrm{n}$ & y & 2004 & Nova Scotia & QB10 & y & $\begin{array}{l}y \\
y\end{array}$ & 2006 & Quebec \\
\hline NF1 & y & $\mathrm{n}$ & 2004 & Newfoundland & QB11 & y & y & 2005 & Quebec \\
\hline NF2 & y & y & 2000 & Newfoundland & QB12 & y & y & 2005 & Quebec \\
\hline NB1 & $y$ & y & 2001 & New Brunswick & QB13 & y & $\mathrm{n}$ & 2004 & Quebec \\
\hline NB2 & y & y & 2003 & New Brunswick & QB14 & y & y & 2004 & Quebec \\
\hline NB3 & y & y & 2004 & New Brunswick & QB15 & y & y & 2004 & Quebec \\
\hline NB4 & y & y & 2004 & New Brunswick & QB16 & y & y & 2003 & Quebec \\
\hline NB5 & y & y & 2004 & New Brunswick & QB17 & y & y & 2001 & Quebec \\
\hline NB6 & y & y & 2004 & New Brunswick & QB18 & y & y & 2001 & Quebec \\
\hline & & & & & QB19 & y & $y$ & 2000 & Quebec \\
\hline PEI1 & $y$ & $y$ & 1994 & Prince Edward & QB20 & y & y & 1999 & Quebec \\
\hline & & & & $\begin{array}{l}\text { Island } \\
\text { Prince Fdward }\end{array}$ & QC21 & $\mathrm{n}$ & y & 2001 & Quebec \\
\hline PEI2 & y & y & 1994 & $\begin{array}{l}\text { Prince Edward } \\
\text { Island }\end{array}$ & ME1 & y & $\mathrm{n}$ & 1994 & Maine \\
\hline PEI3 & $y$ & $y$ & 1994 & Prince Edward & ME2 & y & y & 1999 & Maine \\
\hline & & & & Island & ME3 & y & y & 1999 & Maine \\
\hline PEI4 & $y$ & $y$ & 1994 & Prince Edward & ME4 & y & y & 1996 & Maine \\
\hline & & $y$ & & Island & ME5 & y & y & - & Maine \\
\hline PEI5 & $y$ & $y$ & 1994 & Prince Edward & ME6 & y & y & - & Maine \\
\hline PEIS & y & $y$ & 1994 & $\begin{array}{l}\text { Island } \\
\text { Istance }\end{array}$ & ME7 & $n$ & y & - & Maine \\
\hline PEI6 & y & y & 1995 & Prince Edward & MA1 & y & y & 1999 & Massachusetts \\
\hline & & & & Island & MA2 & $\mathrm{n}$ & y & - & Massachusetts \\
\hline PEI7 & y & y & 1994 & Prince Edward & DE1 & $y$ & y & 1996 & Delaware \\
\hline & & & & Island & DE2 & y & y & 1996 & Delaware \\
\hline PEI8 & y & y & 1994 & Prince Edward & MD1 & y & y & 1995 & Maryland \\
\hline & & & & Island & MD2 & y & y & 1994 & Maryland \\
\hline PEI9 & y & y & 1994 & Prince Edward & MD3 & $y$ & y & 1994 & Maryland \\
\hline & & & & Island & MD4 & y & y & 1994 & Maryland \\
\hline PEI10 & y & y & 1995 & Prince Edward & MD5 & y & y & 1994 & Maryland \\
\hline & & & & Island & MD6 & y & y & 1994 & Maryland \\
\hline PEI11 & y & y & 1994 & Prince Edward & MD7 & y & y & 1997 & Maryland \\
\hline & & & & Island & MD8 & y & y & 1997 & Maryland \\
\hline PEI12 & y & y & 1995 & Prince Edward & MD9 & y & y & 1996 & Maryland \\
\hline & & & & Island & MD10 & y & y & 1998 & Maryland \\
\hline PEI13 & y & y & 1994 & Prince Edward & MD11 & y & y & 1998 & Maryland \\
\hline & & & & Island & MD12 & y & y & 1998 & Maryland \\
\hline PEI14 & y & y & 1995 & Prince Edward & MD13 & y & y & 1998 & Maryland \\
\hline & & & & Island & MD14 & y & y & 1996 & Maryland \\
\hline PEI15 & y & y & 1994 & Prince Edward & MD15 & y & y & 1996 & Maryland \\
\hline & & & & Island & MD16 & y & y & 1996 & Maryland \\
\hline PEI16 & y & y & 1995 & Prince Edward & MD17 & y & $\mathrm{n}$ & 1996 & Maryland \\
\hline & & & & Island & RI1 & $y$ & $y$ & 1995 & Rhode Island \\
\hline PEI17 & y & y & 1994 & Prince Edward & $\mathrm{RI} 2$ & y & y & 1995 & Rhode Island \\
\hline & & & & Islanc & RI3 & y & $\mathrm{n}$ & 1995 & Rhode Island \\
\hline
\end{tabular}


APPENDIX 1. Continued.

\begin{tabular}{|c|c|c|c|c|}
\hline $\begin{array}{l}\text { Genetic } \\
\text { sample ID }\end{array}$ & $\begin{array}{c}\text { Mitochondrial } \\
\text { data }\end{array}$ & $\begin{array}{c}\text { Microsatellite } \\
\text { data }\end{array}$ & $\begin{array}{c}\text { Year } \\
\text { collected }\end{array}$ & $\begin{array}{l}\text { State or } \\
\text { province }\end{array}$ \\
\hline NY1 & y & y & 1996 & New York \\
\hline NY2 & y & y & 1996 & New York \\
\hline NY3 & y & y & 1996 & New York \\
\hline NY4 & y & y & 1996 & New York \\
\hline NY5 & y & y & 1996 & New York \\
\hline NY6 & $y$ & y & 1996 & New York \\
\hline NY7 & $y$ & y & 1996 & New York \\
\hline NY8 & y & y & 1997 & New York \\
\hline NY9 & $y$ & y & 1997 & New York \\
\hline NY10 & $y$ & $y$ & 1997 & New York \\
\hline NY11 & y & y & 1997 & New York \\
\hline NY12 & $y$ & $y$ & 1997 & New York \\
\hline NY13 & y & y & 1997 & New York \\
\hline NY14 & $y$ & $n$ & 1997 & New York \\
\hline NY15 & $y$ & y & 1997 & New York \\
\hline NY16 & y & $y$ & 1997 & New York \\
\hline NY17 & $y$ & $y$ & 1997 & New York \\
\hline NY18 & y & y & 1997 & New York \\
\hline NY19 & y & $n$ & 1997 & New York \\
\hline NY20 & y & y & 1997 & New York \\
\hline NY21 & $n$ & y & 1997 & New York \\
\hline NJ1 & $y$ & $y$ & 1995 & New Jersey \\
\hline NJ2 & y & y & 1995 & New Jersey \\
\hline NJ3 & y & $y$ & 1995 & New Jersey \\
\hline NJ4 & y & y & 1995 & New Jersey \\
\hline NJ5 & $y$ & y & 1995 & New Jersey \\
\hline
\end{tabular}

\begin{tabular}{|c|c|c|c|c|}
\hline $\begin{array}{l}\text { Genetic } \\
\text { sample ID }\end{array}$ & $\begin{array}{l}\text { Mitochondrial } \\
\text { data }\end{array}$ & $\begin{array}{c}\text { Microsatellite } \\
\text { data }\end{array}$ & $\begin{array}{c}\text { Year } \\
\text { collected }\end{array}$ & $\begin{array}{l}\text { State or } \\
\text { province }\end{array}$ \\
\hline NJ6 & $y$ & $y$ & 1995 & New Jersey \\
\hline NJ7 & $y$ & $y$ & 1995 & New Jersey \\
\hline NJ8 & y & $y$ & 1996 & New Jersey \\
\hline NJ9 & y & y & 1992 & New Jersey \\
\hline NJ10 & y & $y$ & 1992 & New Jersey \\
\hline NJ11 & $y$ & $y$ & 1992 & New Jersey \\
\hline NJ12 & $y$ & $y$ & 1992 & New Jersey \\
\hline NJ13 & y & $n$ & 1994 & New Jersey \\
\hline NJ14 & $y$ & $y$ & 1995 & New Jersey \\
\hline NJ15 & $y$ & $y$ & 1995 & New Jersey \\
\hline NJ16 & y & $y$ & 1995 & New Jersey \\
\hline NJ17 & y & y & 1991 & New Jersey \\
\hline NJ18 & y & $y$ & 1992 & New Jersey \\
\hline NJ19 & $y$ & $n$ & 1995 & New Jersey \\
\hline NJ20 & y & $\mathrm{n}$ & 1996 & New Jersey \\
\hline NJ21 & y & $\mathrm{n}$ & 1996 & New Jersey \\
\hline NJ22 & y & $\mathrm{n}$ & 1997 & New Jersey \\
\hline NC1 & $y$ & $y$ & 1995 & North Carolina \\
\hline NC2 & y & y & 1995 & North Carolina \\
\hline NC3 & y & $n$ & 1994 & North Carolina \\
\hline NC4 & $y$ & $y$ & 1995 & North Carolina \\
\hline NC5 & y & y & 1995 & North Carolina \\
\hline NC6 & $y$ & $y$ & 1995 & North Carolina \\
\hline $\mathrm{NC7}$ & y & $n$ & 1995 & North Carolina \\
\hline NC8 & y & $\mathrm{n}$ & 1995 & North Carolina \\
\hline NC9 & $y$ & $y$ & 1996 & North Carolina \\
\hline
\end{tabular}

APPENDIX 2. Geographic locations where 70 unique Piping Plover haplotypes were detected. Only haplotypes 1, 2, 18, and 25 were shared between Interior and Atlantic birds. Abbreviations: $\mathrm{AB}=$ Alberta, $\mathrm{SK}=$ Saskatchewan, $\mathrm{MB}=$ Manitoba, $\mathrm{MT}=\mathrm{Montana}, \mathrm{ND}=\mathrm{North} \mathrm{Dakota}, \mathrm{SD}=\mathrm{South} \mathrm{Dakota}$, $\mathrm{NE}=$ Nebraska, $\mathrm{MN}=$ Minnesota, $\mathrm{WI}=$ Wisconsin, $\mathrm{MI}=$ Michigan, $\mathrm{QB}=$ Quebec, NF = Newfoundland, NB = New Brunswick, PI = Prince Edward Island, NS = Nova Scotia, ME = Maine, MA = Massachusetts, DE = Delaware, MD = Maryland, RI = Rhode Island, NY = New York, NJ = New Jersey, and $\mathrm{NC}=$ North Carolina.

\begin{tabular}{|c|c|c|c|c|c|c|c|c|c|c|c|c|c|c|c|c|c|c|c|c|c|c|c|c|}
\hline \multirow[b]{2}{*}{ Haplotype } & \multicolumn{3}{|c|}{$\begin{array}{l}\text { Prairie } \\
\text { Canada }\end{array}$} & \multicolumn{5}{|c|}{ Northern Great Plains } & \multicolumn{2}{|c|}{$\begin{array}{l}\text { Great } \\
\text { Lakes }\end{array}$} & \multicolumn{5}{|c|}{ Atlantic Canada } & \multicolumn{8}{|c|}{ Atlantic United States } & \multirow[b]{2}{*}{ Total } \\
\hline & $A B$ & SK & $M B$ & MT & ND & SD & NE & $M N$ & WI & MI & QB & NF & NB & PI & NS & ME & MA & $\mathrm{DE}$ & MD & $\mathrm{RI}$ & NY & NJ & NC & \\
\hline 1 & 1 & 7 & 1 & 2 & 6 & 9 & & 1 & 1 & 10 & & & & 2 & & & & & & & & & & 40 \\
\hline 2 & 2 & 2 & 1 & & 6 & 4 & & & & 1 & & 1 & 2 & & 4 & & & & & & & & & 23 \\
\hline 3 & 2 & & & & & & & & & & & & & & & & & & & & & & & 2 \\
\hline 4 & 1 & & 1 & & & & & & & & & & & & & & & & & & & & & 2 \\
\hline 5 & 1 & & & & & & & & & & & & & & & & & & & & & & & 1 \\
\hline 6 & & 3 & & & 2 & & & & & & & & & & & & & & & & & & & 5 \\
\hline 7 & & 1 & & & & & & & & & & & & & & & & & & & & & & 1 \\
\hline 8 & & 1 & & & & & & & & & & & & & & & & & & & & & & 1 \\
\hline 9 & & 3 & & & & & & & & & & & & & & & & & & & & & & 3 \\
\hline 10 & & 1 & & & & & & & & & & & & & & & & & & & & & & 1 \\
\hline 11 & & 1 & & & & & & & & & & & & & & & & & & & & & & 1 \\
\hline 12 & & & & 1 & & & 1 & & & & & & & & & & & & & & & & & 2 \\
\hline 13 & & & & 1 & & & & & & 1 & & & & & & & & & & & & & & 2 \\
\hline 14 & & & & & 3 & & & & & & & & & & & & & & & & & & & 3 \\
\hline 15 & & & & & 2 & 1 & & & & 1 & & & & & & & & & & & & & & 4 \\
\hline 16 & & & & & 1 & & & & & & & & & & & & & & & & & & & 1 \\
\hline 17 & & & & & & 2 & & & & & & & & & & & & & & & & & & 2 \\
\hline 18 & & & & & & 1 & 1 & & & & & & & & & & & & & & & & 1 & 3 \\
\hline 19 & & & & & & 1 & & & & & & & & & & & & & & & & & & 1 \\
\hline 20 & & & & & & 1 & & & & & & & & & & & & & & & & & & 1 \\
\hline
\end{tabular}


ApPendix 2. Continued.

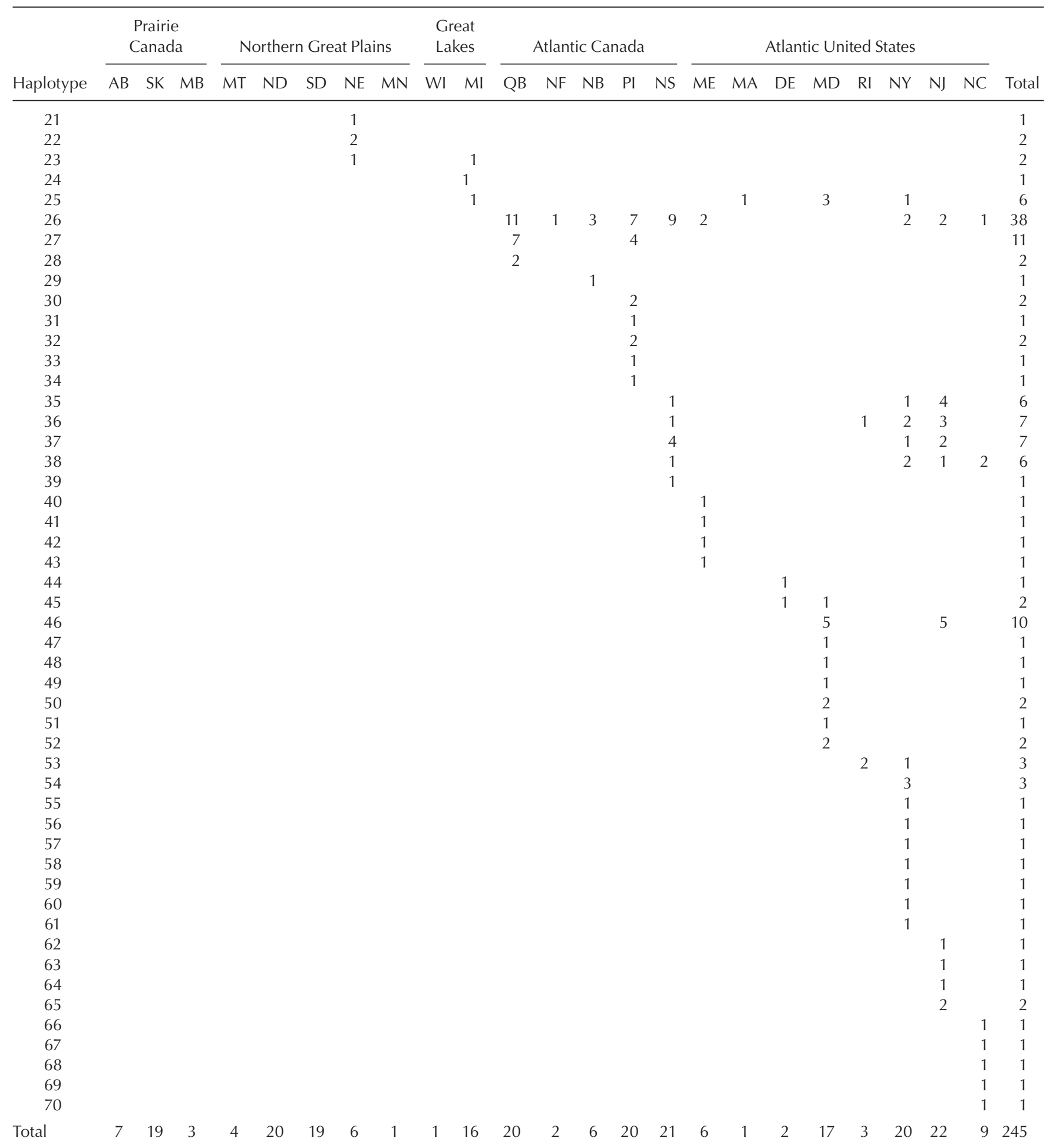


APPENDIX 3. Observed allele frequencies at 8 microsatellite loci in each of 5 geographic regions described in the text.

\begin{tabular}{|c|c|c|c|c|c|c|c|}
\hline & \multicolumn{6}{|c|}{ Geographic region } & \multirow[b]{2}{*}{ Total } \\
\hline & $\begin{array}{l}\text { Allele } \\
\text { size }\end{array}$ & $\begin{array}{l}\text { Prairie } \\
\text { Canada }\end{array}$ & $\begin{array}{l}\text { U.S. Great } \\
\text { Plains }\end{array}$ & $\begin{array}{l}\text { Great } \\
\text { Lakes }\end{array}$ & $\begin{array}{l}\text { Atlantic } \\
\text { Canada }\end{array}$ & $\begin{array}{c}\text { Atlantic United } \\
\text { States }\end{array}$ & \\
\hline \multirow[t]{3}{*}{ Locus C-201 } & 168 & 0.222 & 0.353 & 0.250 & 0.136 & 0.371 & 0.274 \\
\hline & 170 & 0.667 & 0.588 & 0.500 & 0.864 & 0.579 & 0.669 \\
\hline & 172 & 0.111 & 0.059 & 0.250 & 0.000 & 0.050 & 0.057 \\
\hline$n$ & & 27 & 51 & 14 & 66 & 70 & 228 \\
\hline \multirow[t]{2}{*}{ Locus PLL-11 } & 223 & 0.370 & 0.451 & 0.357 & 0.597 & 0.739 & 0.566 \\
\hline & 227 & 0.630 & 0.549 & 0.643 & 0.403 & 0.261 & 0.434 \\
\hline$n$ & & 27 & 51 & 14 & 67 & 69 & 228 \\
\hline \multirow[t]{3}{*}{ Locus PLL-4 } & 180 & 0.327 & 0.370 & 0.143 & 0.067 & 0.044 & 0.162 \\
\hline & 186 & 0.673 & 0.630 & 0.857 & 0.530 & 0.732 & 0.650 \\
\hline & 188 & 0.000 & 0.000 & 0.000 & 0.403 & 0.225 & 0.188 \\
\hline$n$ & & 26 & 50 & 14 & 67 & 69 & 226 \\
\hline \multirow[t]{2}{*}{ Locus PLL-10 } & 216 & 0.212 & 0.128 & 0.286 & 0.000 & 0.000 & 0.070 \\
\hline & 218 & 0.789 & 0.873 & 0.714 & 1.000 & 1.000 & 0.930 \\
\hline$n$ & & 26 & 51 & 14 & 67 & 70 & 228 \\
\hline \multirow[t]{2}{*}{ Locus Calex-13 } & 148 & 0.259 & 0.190 & 0.321 & 0.311 & 0.228 & 0.253 \\
\hline & 149 & 0.741 & 0.810 & 0.679 & 0.689 & 0.772 & 0.747 \\
\hline$n$ & & 27 & 50 & 14 & 66 & 68 & 225 \\
\hline \multirow[t]{4}{*}{ Locus Calex-8 } & 210 & 0.037 & 0.000 & 0.000 & 0.000 & 0.000 & 0.004 \\
\hline & 212 & 0.630 & 0.847 & 0.786 & 1.000 & 0.900 & 0.879 \\
\hline & 214 & 0.019 & 0.000 & 0.000 & 0.000 & 0.000 & 0.002 \\
\hline & 216 & 0.315 & 0.153 & 0.214 & 0.000 & 0.100 & 0.115 \\
\hline$n$ & & 27 & 49 & 14 & 67 & 70 & 227 \\
\hline \multirow[t]{5}{*}{ Locus Calex-37 } & 162 & 0.000 & 0.000 & 0.000 & 0.015 & 0.064 & 0.024 \\
\hline & 163 & 0.111 & 0.157 & 0.179 & 0.000 & 0.000 & 0.059 \\
\hline & 164 & 0.778 & 0.804 & 0.821 & 0.970 & 0.914 & 0.884 \\
\hline & 165 & 0.111 & 0.039 & 0.000 & 0.015 & 0.000 & 0.026 \\
\hline & 166 & 0.000 & 0.000 & 0.000 & 0.000 & 0.021 & 0.007 \\
\hline$n$ & & 27 & 51 & 14 & 67 & 70 & 229 \\
\hline \multirow[t]{2}{*}{ Locus Calex-35 } & 130 & 0.130 & 0.343 & 0.107 & 0.000 & 0.036 & 0.109 \\
\hline & 132 & 0.870 & 0.657 & 0.893 & 1.000 & 0.964 & 0.891 \\
\hline$n$ & & 27 & 51 & 14 & 67 & 70 & 229 \\
\hline
\end{tabular}

